\title{
Analisis Kestabilan dan Kontrol Optimal Model Matematika Dinamika Pelanggan Berdasarkan Kebijakan Pemasaran
}

\author{
Muhammad Iqbal Abdi Farchan ${ }^{1}$, Fatmawati ${ }^{2}$ \& Cicik Alfiniyah ${ }^{3}$ \\ ${ }^{1,2,3}$ Departemen Matematika, Fakultas Sains dan Teknologi, Kampus C \\ Universitas Airlangga, Jl. Mulyorejo, Surabaya \\ ${ }^{3}$ Corresponding author: cicik-a@fst.unair.ac.id
}

\begin{abstract}
Customer dynamics include the exchange of information and ongoing transactions between customers and the organization. This process has an important role in the company to run its business, so that the number of customers increase. To achieve this, many things are done by the company. One of the strategies is product advertising by word of mouth. The purpose of this thesis is to analyze the stability of equilibrium point and to apply the optimal control word of mouth advertising on mathematics model of the customer dynamics based on marketing policy. Mathematics model of the customer dynamics based on marketing policy without control has two equilibrium points, namely non - endemic equilibrium $\left(E_{0}\right)$ and endemic equilibrium $\left(E_{1}\right)$. Local stability of equilibrium and the existence of endemic equilibrium depends on basic reproduction number $\left(R_{0}\right)$. The non - endemic equilibrium tend to asymptotically stable if $R_{0}<1$. The problem of optimal control is solved by Pontryagin's Maximum Principle. The simulation results show that the total number of referral and regular customer populations that are given control in the form of word of mouth advertising efforts at the end of the observation are 312 and 18470 with the control effort costs occurred in 1798364.63. While the total number of referral and regular customer populations that are not given control in the form of word of mouth advertising efforts at the end observation are 241 and 17260. Based on these results show that word of mouth advertising efforts have an effect to increase the number of referral and regular customer in accordance with the aim of providing optimal control.
\end{abstract}

Keywords: customer dynamics, mathematics model, optimal control, stability, word of mouth advertising.

\section{Pendahuluan}

Setiap perusahaan memiliki keinginan agar produk yang ditawarkan kepada konsumen laku terjual. Oleh karena itu setiap perusahaan memiliki kebijakan pemasaran agar produk yang ditawarkan menarik perhatian konsumen. Bahkan menurut laporan CMO (Credit Marketing Officer) pada tahun 2017 yang dilakukan oleh (Fuqua School of Busines), Assosiasi pemasaran Amerika dan Deloitte menunjukkan bahwa pendapatan perusahaan dialokasikan untuk anggaran pemasaran antara $10 \%$ dan $20 \%$. Dengan demikian pemasaran merupakan salah satu elemen penting di perusahaan yang tidak bisa dipandang sebelah mata [1]. 
Pemasaran pada umumnya memiliki target agar pelanggan dapat dipertahankan selamanya. Hal ini tentu tidak mudah mengingat perubahan-perubahan dapat terjadi setiap saat, baik perubahan yang terjadi pada pelanggan seperti selera, minat maupun perubahan yang terjadi pada lingkungan. Masa krisis yang terjadi pada pertengahan tahun 1997 merupakan salah satu contoh perubahan yang terjadi pada lingkungan. Hal ini berdampak pada daya beli pelanggan. Daya beli pelanggan yang menurun tajam menandakan bahwa harga barang yang ada dipasaran melambung tinggi. Meskipun pemasar memiliki segmen pelanggan yang dianggap loyal, dalam kondisi krisis, pemasar harus tetap bisa mempertahankan merk mereka. Hal-hal yang perlu dilakukan yaitu dengan mempertahankan kualitas, memberikan pelayanan yang memuaskan, dan menentukan harga yang terjangkau di pasaran [2].

Beberapa penelitian menyebutkan bahwa pelanggan suatu perusahaan dapat diklasifikasikan ke dalam beberapa kelompok sesuai dengan peran mereka yang berpengaruh terhadap pelanggan lainnya. Kelompok pelanggan tersebut adalah pelanggan referral, regular, dan potensial. Pelanggan referral adalah pelanggan yang sering membeli produk di suatu perusahaan, disamping itu mereka merekomendasikannya ke pelanggan lain. Pelanggan regular adalah pelanggan yang sering membeli produk di suatu perusahaan tanpa merekomendasikannya ke orang lain. Sedangkan Pelanggan potensial adalah calon konsumen setia dari suatu produk perusahaan tertentu. Dari ketiga definisi pelanggan tersebut dapat diketahui bahwa, pelanggan referral merupakan tipe pelanggan yang menguntungkan bagi perusahaan, karena sifat pelanggan ini disamping membeli produk, mereka dapat mempengaruhi orang lain untuk menjadi pelanggan dari suatu perusahaan. Dengan demikian, perusahaan lebih mengutamakan pelanggan referral karena sifat yang dimilikinya. Walaupun semua pelanggan penting, pelanggan referral tetap lebih berharga karena dapat membantu perusahaan untuk mengungguli persaingan yang ada di pasar [3].

Selain memperhatikan pelanggan, perusahaan juga harus memperhatikan bagaimana cara mempromosikan produknya. Salah satu cara yang mudah dilakukan yaitu dengan pengiklanan melalui mulut ke mulut (word of mouth). Word of mouth adalah suatu kegiatan komunikasi pemasaran melalui promosi yang dilakukan pelanggan ke pelanggan lain, baik melalui lisan, tulisan maupun elektronik yang dipergunakan masyarakat untuk bertukar pikiran tentang pengalamannya dan pengetahuan sebuah perusahaan, produk atau jasa. Pengiklanan word of mouh memiliki banyak keungggulan diantaranya yaitu lebih meyakinkan dan berbiaya rendah. Oleh karena itu banyak perusahaan yang menjadikan iklan dengan metode word of mouth sebagai sarana untuk mempromosikan produknya [4].

Dinamika pelanggan yang turut berkontribusi bagi perusahaan dalam mendapat keuntungan sangat menarik untuk dikaji . Salah satunya pada bidang matematika, yaitu dengan pendekatan model matematika. Terdapat beberapa peneliti yang membahas 
tentang model matematika dinamika pelanggan. Silva dkk [3] pertama kali mengusulkan model persamaan diferensial biasa tentang dinamika pelanggan dengan memperhatikan faktor biaya referral marketing. Pada model Silva dkk [3] terdapat empat kompartemen yaitu, pelanggan referral, regular, potensial referral, dan potensial regular. Rosa dkk [1] mengkontruksikan model dinamika pelanggan dengan memberikan dua variabel kontrol yaitu, pengiklanan suatu produk di media massa dan pengiklanan melalui mulut ke mulut. Terdapat tiga kompartemen yang digunakan pada model tersebut yaitu, pelanggan referral, regular, dan potensial. Li dkk [5] mengkontruksikan model penyebaran pengiklanan melalui word of mouth dengan memperhatikan komentar positif dan negatif. Terdapat empat kompartemen yang digunakan yakni populasi manusia yang rentan yaitu populasi yang akan membeli barang, populasi manusia yang terinfeksi yaitu populasi yang telah membeli barang tapi belum berkomentar, populasi manusia yang berkomentar positif, populasi manusia yang berkomentar negatif.

Pada penelitian ini penulis tertarik untuk membahas model matematika dinamika pelanggan berdasarkan kebijakan pemasaran. Model yang digunakan merujuk pada model yang ditulis oleh Rosa dkk [1] dengan memodifikasi adanya laju kelahiran dan kematian serta menambahkan satu kompartemen dengan cara membagi populasi pelanggan potensial menjadi dua sub populasi, yakni populasi pelanggan potensial referral dan populasi pelanggan potensial regular. Variabel kontrol yang diberikan berupa pengiklanan produk melalui word of mouth.

\section{Formulasi Model}

Pada bagian ini akan diformulasikan model matematika dinamika pelanggan berdasarkan kebijakan pemasaran. Adapun asumsi yang digunakan untuk kontruksi model sebagai berikut :

a. Semua populasi yang menjadi populasi yang dituju dapat kembali menjadi populasi semula.

b. Hanya populasi pelanggan referral yang dapat mempengaruhi populasi pelanggan potensial menjadi populasi pelanggan referral dan regular.

c. Perubahan populasi pelanggan regular menjadi populasi pelanggan referral tanpa ada pengaruh dari populasi pelanggan referral.

Model dasar dinamika pelanggan berdasarkan kebijakan pemasaran merujuk pada jurnal yang ditulis oleh Rosa dkk [1]. Pada model tersebut terdapat tiga kompartemen yaitu populasi pelanggan referral $(R)$, populasi pelanggan regular $(C)$, dan populasi pelanggan potensial $(P)$ dengan asumsi mengabaikan laju kelahiran dan kematian. Pada skripsi ini dilakukan modifikasi model dengan memperhatikan laju kelahiran dan kematian serta menambahkan satu kompartemen dengan cara membagi populasi pelanggan potensial 
menjadi dua sub populasi, yakni populasi pelanggan potensial referral $\left(P_{R}\right)$ dan populasi pelanggan potensial regular $\left(P_{C}\right)$. Pendefinisian parameter dapat dilihat pada Tabel 1 berikut.

Tabel 1 Pendefinisian Parameter Model

\begin{tabular}{|c|c|}
\hline Notasi & Keterangan \\
\hline$\Lambda$ & Laju rekruitmen pelanggan \\
\hline$\alpha$ & Proporsi laju rekruitmen pelanggan \\
\hline$\mu$ & $\begin{array}{l}\text { Laju hilangnya pelanggan karena kematian, emigrasi, dan kehilangan } \\
\text { kepercayaan terhadap suatu produk }\end{array}$ \\
\hline$\eta_{1}$ & Laju transisi dari pelanggan potensial regular ke pelanggan potensial referral \\
\hline$\eta_{2}$ & Laju transisi dari pelanggan potensial referral ke pelanggan potensial regular \\
\hline$\delta$ & $\begin{array}{l}\text { Laju perubahan pelanggan potensial ke pelanggan referral atau regular } \\
\text { karena pengaruh pelanggan referral }\end{array}$ \\
\hline$\omega_{1}$ & Laju transisi dari pelanggan regular ke pelanggan referral \\
\hline$\omega_{2}$ & Laju transisi dari pelanggan referral ke pelanggan regular \\
\hline$\beta_{1}$ & $\begin{array}{l}\text { Laju berkurangnya pelanggan reguler karena menjadi pelanggan potensial } \\
\text { regular }\end{array}$ \\
\hline$\beta_{2}$ & $\begin{array}{l}\text { Laju berkurangnya pelanggan referral karena menjadi pelanggan potensial } \\
\text { referral }\end{array}$ \\
\hline
\end{tabular}

Berdasarkan asumsi dan pendefinisian parameter serta variabel dapat dibentuk diagram transmisi yang disajikan pada Gambar 1 sebagai berikut.

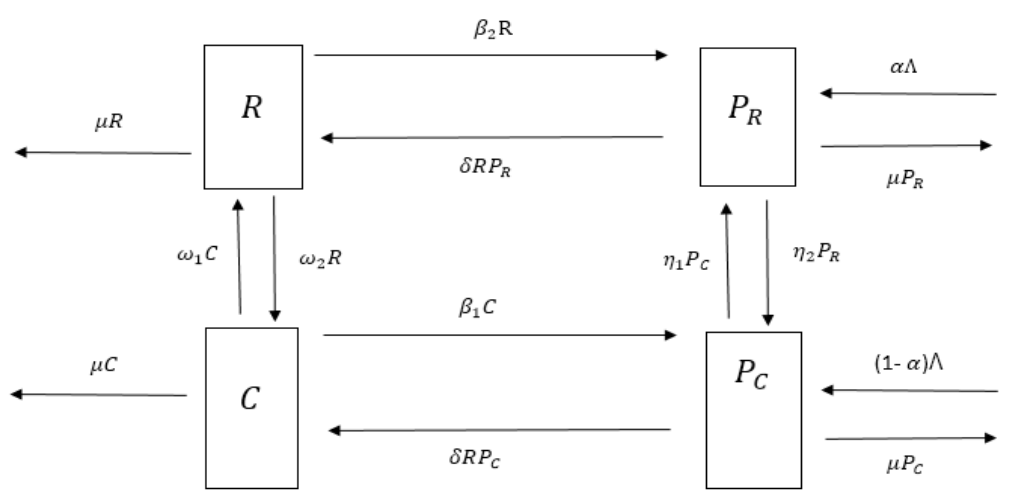

Gambar 1 Diagram Transmisi Model 
Dari diagram transmisi pada Gambar 1 dapat diformulasikan model sebagai berikut:

$$
\begin{aligned}
& \frac{d P_{R}}{d t}=\alpha \Lambda+\beta_{2} R+\eta_{1} P_{C}-\left(\mu+\eta_{2}\right) P_{R}-\delta R P_{R} \\
& \frac{d P_{C}}{d t}=(1-\alpha) \Lambda+\beta_{1} C+\eta_{2} P_{R}-\left(\mu+\eta_{1}\right) P_{C}-\delta R P_{C} \\
& \frac{d R}{d t}=\omega_{1} C-\left(\mu+\beta_{2}+\omega_{2}\right) R+\delta R P_{R} \\
& \frac{d C}{d t}=\omega_{2} R-\left(\mu+\beta_{1}+\omega_{1}\right) C+\delta R P_{C}
\end{aligned}
$$

dengan $R, C, P_{C}, P_{R} \geq 0, \Lambda, \alpha, \mu, \eta_{1}, \eta_{2}, \delta, \omega_{1}, \omega_{2}, \beta_{1}, \beta_{2}>0$.

Persamaan (1) menyatakan laju perubahan populasi pelanggan potensial referral per satuan waktu. Populasi ini bertambah karena kelahiran atau imigrasi, dan perubahan populasi pelanggan referral menjadi populasi pelanggan potensial referral. Populasi ini bertambah karena perubahan populasi pelanggan potensial regular menjadi populasi pelanggan potensial referral. Populasi ini berkurang karena populasi pelanggan potensial referral menjadi populasi pelanggan referral akibat pengaruh dari pelanggan referral dan berkurang pula karena menjadi populasi pelanggan potensial regular. Populasi ini juga berkurang karena kematian alami, emigrasi, dan kehilangan kepercayaan terhadap suatu produk.

Persamaan (2) menyatakan laju perubahan populasi pelanggan potensial regular per satuan waktu. Populasi ini bertambah karena kelahiran atau imigrasi, dan perubahan populasi pelanggan regular menjadi populasi pelanggan potensial regular. Populasi ini bertambah karena perubahan populasi pelanggan potensial referral menjadi populasi pelanggan potensial regular. Populasi ini berkurang karena populasi pelanggan potensial regular menjadi populasi pelanggan regular akibat pengaruh dari pelanggan referral dan berkurang pula karena menjadi populasi pelanggan potensial referral. Populasi ini juga berkurang karena kematian alami, emigrasi, dan kehilangan kepercayaan terhadap suatu produk.

Persamaan (3) menyatakan laju perubahan populasi pelanggan referral per satuan waktu. Populasi ini bertambah karena populasi pelanggan potensial referral menjadi populasi pelanggan referral akibat pengaruh dari pelanggan referral. Populasi ini juga bertambah karena perubahan populasi pelanggan regular menjadi populasi pelanggan referral. Populasi ini berkurang karena populasi pelanggan referral menjadi populasi pelanggan potensial referral dan pelanggan regular. Populasi ini juga berkurang karena kematian alami, emigrasi, dan kehilangan kepercayaan terhadap suatu produk. 
Persamaan (4) menyatakan laju perubahan populasi pelanggan regular per satuan waktu. Populasi ini bertambah karena populasi pelanggan potensial regular menjadi populasi pelanggan regular akibat pengaruh dari pelanggan referral. Populasi ini juga bertambah karena perubahan populasi pelanggan referral menjadi pelanggan regular. Populasi ini berkurang karena populasi pelanggan regular menjadi populasi pelanggan potensial regular dan pelanggan referral. Populasi ini juga berkurang karena kematian alami, emigrasi, dan kehilangan kepercayaan terhadap suatu produk.

\section{Titik Setimbang Model}

Model matematika dinamika pelanggan berdasarkan kebijakan pemasaran memiliki dua titik setimbang, yaitu titik setimbang non endemik $\left(E_{0}\right)$ dan titik setimbang endemik $\left(E_{1}\right)$. Titik setimbang non endemik dari model tersebut adalah $E_{0}=\left(P_{R}{ }^{0}, P_{C}{ }^{0}, R^{0}, C^{0}\right)=$ $\left(\frac{\Lambda}{\mu} \frac{\alpha \mu+\eta_{1}}{\mu+\eta_{2}+\eta_{1}}, \frac{\Lambda}{\mu} \frac{(1-\alpha) \mu+\eta_{2}}{\mu+\eta_{2}+\eta_{1}}, 0,0\right)$.

Selanjutnya, dari titik setimbang non endemik $E_{0}$ dengan menggunakan metode Next Generation Matrix [6] dapat diperoleh bilangan reproduksi dasar $\left(R_{0}\right)$ berikut:

$$
\mathrm{R}_{0}=\frac{\Lambda \delta\left(\left(\alpha \mu+\eta_{1}\right)\left(\mu+\beta_{1}+\omega_{1}\right)+\omega_{1}\left[(1-\alpha) \mu+\eta_{2}\right]\right)}{\mu\left(\mu+\eta_{2}+\eta_{1}\right)\left(\left(\mu+\beta_{2}\right)\left(\mu+\beta_{1}+\omega_{1}\right)+\omega_{2}\left(\mu+\beta_{1}\right)\right)}
$$

Dari hasil perhitungan diperoleh titik setimbang endemik $E_{1}=\left(P_{R}^{*}, P_{C}^{*}, R^{*}, C^{*}\right)$ dari model tersebut adalah sebagai berikut.

$$
\begin{array}{ccc}
P_{R}^{*} & \\
= & \frac{\left(\alpha \Lambda+\beta_{2} R^{*}\right)\left[\mu\left(\mu+\eta_{2}+\delta R^{*}\right)+\eta_{1}\left(\mu+\delta R^{*}\right)+\delta R^{*}\left(\mu+\eta_{2}+\delta R^{*}\right)\right]}{\left[\mu\left(\mu+\eta_{2}+\delta R^{*}\right)+\eta_{1}\left(\mu+\delta R^{*}\right)+\delta R^{*}\left(\mu+\eta_{2}+\delta R^{*}\right)\right]\left(\mu+\eta_{2}+\delta R^{*}\right)} \\
+ & \frac{(1-\alpha) \Lambda \eta_{1}\left(\mu+\eta_{2}+\delta R^{*}\right)+\eta_{1} \beta_{1} C^{*}\left(\mu+\eta_{2}+\delta R^{*}\right)}{\left[\mu\left(\mu+\eta_{2}+\delta R^{*}\right)+\eta_{1}\left(\mu+\delta R^{*}\right)+\delta R^{*}\left(\mu+\eta_{2}+\delta R^{*}\right)\right]\left(\mu+\eta_{2}+\delta R^{*}\right)} \\
+ & \frac{\eta_{1} \eta_{2} \alpha \Lambda+\eta_{1} \eta_{2} \beta_{2} R^{*}}{\left[\mu\left(\mu+\eta_{2}+\delta R^{*}\right)+\eta_{1}\left(\mu+\delta R^{*}\right)+\delta R^{*}\left(\mu+\eta_{2}+\delta R^{*}\right)\right]\left(\mu+\eta_{2}+\delta R^{*}\right)} \\
P_{C}^{*}= & \frac{(1-\alpha) \Lambda\left(\mu+\eta_{2}+\delta R^{*}\right)+\beta_{1} C^{*}\left(\mu+\eta_{2}+\delta R^{*}\right)+\eta_{2} \alpha \Lambda+\eta_{2} \beta_{2} R^{*}}{\mu\left(\mu+\eta_{2}+\delta R^{*}\right)+\eta_{1}\left(\mu+\delta R^{*}\right)+\delta R^{*}\left(\mu+\eta_{2}+\delta R^{*}\right)} \\
C^{*}= & \frac{\mu \omega_{2}\left(\mu+\eta_{2}+\delta R^{*}\right) R^{*}+\eta_{1} \omega_{2}\left(\mu+\delta R^{*}\right) R^{*}+\delta \omega_{2}\left(\mu+\eta_{2}+\delta R^{*}\right) R^{2 *}}{\left(\mu+\omega_{1}\right)\left[\mu\left(\mu+\eta_{2}+\delta R^{*}\right)+\eta_{1}\left(\mu+\delta R^{*}\right)+\delta R^{*}\left(\mu+\eta_{2}+\delta R^{*}\right)\right]+\beta_{1}\left[\mu\left(\mu+\eta_{2}+\delta R^{*}\right)+\eta_{1}\left(\mu+\delta R^{*}\right)\right]}+ \\
& \frac{(1-\alpha) \Lambda \delta\left(\mu+\eta_{2}+\delta R^{*}\right) R^{*}+\delta \eta_{2} \alpha \Lambda R^{*}+\delta \eta_{2} \beta_{2} R^{2 *}}{\left(\mu+\omega_{1}\right)\left[\mu\left(\mu+\eta_{2}+\delta R^{*}\right)+\eta_{1}\left(\mu+\delta R^{*}\right)+\delta R^{*}\left(\mu+\eta_{2}+\delta R^{*}\right)\right]+\beta_{1}\left[\mu\left(\mu+\eta_{2}+\delta R^{*}\right)+\eta_{1}\left(\mu+\delta R^{*}\right)\right]}
\end{array}
$$

Sedangkan $R^{*}$ merupakan akar dari polinomial berderajat lima berikut:

$$
r_{1} R^{5}+r_{2} R^{4}+r_{3} R^{3}+r_{4} R^{2}+r_{5} R+r_{6}=0
$$


dengan

$$
\begin{aligned}
& r_{1}=-\mu \omega_{1} \delta^{5}-\mu^{2} \delta^{5}-\omega_{2} \mu \delta^{5} \\
& r_{2}=-3 \omega_{2} \mu \delta^{4} \eta_{1}-2 \mu^{2} \delta^{4} \eta_{1}-\delta^{4} \beta_{2} \eta_{2} \mu-5 \omega_{2} \mu^{2} \delta^{4}-5 \mu^{3} \delta^{4}-\delta^{4} \beta_{2} \mu \omega_{1}+\delta^{5} \alpha \Lambda \mu-3 \mu \omega_{1} \delta^{4} \eta_{2}- \\
& \delta^{4} \beta_{2} \mu^{2}-2 \omega_{2} \mu \delta^{4} \eta_{1}-\delta^{4} \beta_{1} \mu^{2}-\mu \beta_{1} \delta^{4} \eta_{1}-3 \mu^{2} \delta^{4} \eta_{2}-5 \omega_{1} \mu^{2} \delta^{4}-\omega_{2} \mu \beta_{1} \delta^{4}-2 \omega_{1} \mu \delta^{4} \eta_{1}+ \\
& (1-\alpha) \omega_{1} \Lambda \delta^{5}+\delta^{5} \alpha \Lambda \omega_{1} \\
& r_{3}=-4 \delta^{3} \beta_{2} \mu^{3}-10 \omega_{1} \mu^{3} \delta^{3}-8 \mu^{3} \delta^{3} \eta_{1}-12 \mu^{3} \delta^{3} \eta_{2}-3 \mu^{2} \delta^{3} \eta_{2}^{2}-4 \beta_{1} \mu^{3} \delta^{3}-10 \omega_{2} \mu^{3} \delta^{3}- \\
& \mu^{2} \eta_{1}^{2} \delta^{3}-8 \omega_{1} \eta_{1} \mu^{2} \delta^{3}-8 \omega_{2} \eta_{1} \mu^{2} \delta^{3}-4 \omega_{2} \beta_{1} \mu^{2} \delta^{3}-5 \beta_{1} \eta_{1} \mu^{2} \delta^{3}-3 \mu \omega_{1} \delta^{3} \eta_{2}^{2}-3 \omega_{2} \mu \delta^{3} \eta_{2}^{2}- \\
& \mu \omega_{1} \eta_{1}^{2} \delta^{3}-\mu \beta_{1} \eta_{1}^{2} \delta^{3}-\omega_{2} \mu \eta_{1}^{2} \delta^{3}-12 \omega_{2} \mu^{2} \delta^{3} \eta_{2}-4 \mu^{2} \delta^{3} \eta_{1} \eta_{2}-12 \omega_{1} \mu^{2} \delta^{3} \eta_{2}-3 \beta_{1} \mu^{2} \delta^{3} \eta_{2}- \\
& 4 \delta^{3} \beta_{2} \mu^{2} \omega_{1}-6 \delta^{3} \beta_{2} \mu^{2} \eta_{2}-2 \delta^{3} \beta_{2} \mu^{2} \eta_{1}-\delta^{3} \beta_{2} \mu^{2} \beta_{1}-2 \delta^{3} \beta_{2} \eta_{2}^{2} \mu+4 \delta^{4} \alpha \Lambda \mu^{2}-10 \mu^{4} \delta^{3}- \\
& \delta^{3} \beta_{2} \eta_{2} \eta_{1} \mu-\delta^{3} \beta_{2} \eta_{2} \beta_{1} \mu-2 \beta_{1} \eta_{1} \delta^{3} \mu \omega_{2}-3 \omega_{2} \beta_{1} \mu \delta^{3} \eta_{2}-4 \mu \omega_{1} \eta_{1} \delta^{3} \eta_{2}-2 \mu \beta_{1} \eta_{1} \delta^{3} \eta_{2}- \\
& 4 \mu \omega_{2} \delta^{3} \eta_{1} \eta_{2}-3 \omega_{1} \delta^{3} \beta_{2} \eta_{2} \mu-2 \delta^{3} \beta_{2} \mu \omega_{1} \eta_{1}-\delta^{3} \beta_{2} \mu \beta_{1} \eta_{1}+(1-\alpha) \Lambda \delta^{4} \eta_{1} \mu+\beta_{1} \eta_{1}(1- \\
& \alpha) \Lambda \delta^{4}+\delta^{4} \alpha \Lambda \beta_{1} \mu+\delta^{4} \alpha \Lambda \beta_{1} \eta_{1}+4(1-\alpha) \omega_{1} \Lambda \delta^{4} \mu+3(1-\alpha) \omega_{1} \Lambda \delta^{4} \eta_{2}+2(1- \\
& \alpha) \omega_{1} \Lambda \delta^{4} \eta_{1}+3 \omega_{1} \delta^{4} \eta_{2} \alpha \Lambda+4 \omega_{1} \delta^{4} \alpha \Lambda \mu+2 \delta^{4} \alpha \Lambda \eta_{1} \mu+2 \delta^{4} \alpha \Lambda \eta_{1} \omega_{1}+2 \delta^{4} \alpha \Lambda \eta_{2} \mu \\
& r_{4}=-18 \mu^{4} \delta^{2} \eta_{2}-12 \mu^{4} \delta^{2} \eta_{1}-\mu^{2} \delta^{2} \eta_{2}^{3}-10 \omega_{1} \mu^{4} \delta^{2}-10 \omega_{2} \mu^{4} \delta^{2}-9 \mu^{3} \delta^{2} \eta_{2}^{2}-3 \mu^{3} \eta_{1}^{2} \delta^{2}- \\
& 6 \beta_{1} \mu^{4} \delta^{2}-6 \delta^{2} \beta_{2} \mu^{4}-12 \omega_{1} \eta_{1} \mu^{3} \delta^{2}-3 \omega_{1} \mu^{2} \eta_{1}^{2} \delta^{2}-9 \omega_{2} \mu^{2} \eta_{2}^{2} \delta^{2}-12 \omega_{2} \mu^{3} \eta_{1} \delta^{2}- \\
& 3 \omega_{2} \mu^{2} \eta_{1}^{2} \delta^{2}-6 \omega_{2} \beta_{1} \mu^{3} \delta^{2}-9 \beta_{1} \eta_{1} \mu^{3} \delta^{2}-3 \beta_{1} \mu^{2} \eta_{1}^{2} \delta^{2}-9 \omega_{1} \mu^{2} \eta_{2}^{2} \delta^{2}-2 \mu^{2} \eta_{1} \eta_{2}^{2} \delta^{2}- \\
& 3 \beta_{1} \mu^{2} \delta^{2} \eta_{2}^{2}-\mu \omega_{1} \delta^{2} \eta_{2}^{3}-\beta_{2} \mu \delta^{2} \eta_{2}^{3}-\omega_{2} \mu \delta^{2} \eta_{2}^{3}-12 \mu^{3} \delta^{2} \eta_{1} \eta_{2}-\mu^{2} \eta_{1}^{2} \delta^{2} \eta_{2}-18 \omega_{1} \mu^{3} \delta^{2} \eta_{2}- \\
& 9 \beta_{1} \mu^{3} \delta^{2} \eta_{2}-18 \omega_{2} \mu^{3} \delta^{2} \eta_{2}-6 \beta_{2} \mu^{3} \delta^{2} \eta_{1}-12 \beta_{2} \mu^{3} \delta^{2} \eta_{2}-6 \delta^{2} \beta_{2} \mu^{3} \omega_{1} \\
& -3 \delta^{2} \beta_{2} \mu^{3} \beta_{1}-7 \delta^{2} \beta_{2} \mu^{2} \eta_{2}^{2}-\delta^{2} \beta_{2} \mu^{2} \eta_{1}^{2}+6 \delta^{3} \alpha \Lambda \mu^{3}-10 \mu^{5} \delta^{2}-\delta^{2} \beta_{2} \eta_{1}^{2} \mu \beta_{1}-2 \delta^{2} \beta_{2} \eta_{2}^{2} \mu \beta_{1}- \\
& \delta^{2} \beta_{2} \eta_{2}^{2} \eta_{1} \mu-6 \beta_{1} \delta^{2} \eta_{1} \mu^{2} \omega_{2}-\beta_{1} \delta^{2} \eta_{1}^{2} \omega_{2} \mu-12 \omega_{1} \eta_{1} \mu^{2} \delta^{2} \eta_{2}-12 \omega_{2} \mu^{2} \eta_{1} \eta_{2} \delta^{2}- \\
& 8 \beta_{1} \eta_{1} \mu^{2} \delta^{2} \eta_{2}-3 \omega_{2} \beta_{1} \mu \eta_{2}^{2} \delta^{2}-2 \mu \omega_{1} \eta_{1} \eta_{2}^{2} \delta^{2}-\eta_{1} \mu \beta_{1} \eta_{2}^{2} \delta^{2}-2 \omega_{2} \mu \eta_{1} \delta^{2} \eta_{2}^{2}-\mu \omega_{1} \eta_{1}^{2} \delta^{2} \eta_{2}- \\
& \mu \beta_{1} \eta_{1}^{2} \delta^{2} \eta_{2}-\omega_{2} \mu \eta_{1}^{2} \delta^{2} \eta_{2}-4 \omega_{1} \delta^{2} \eta_{2} \beta_{2} \eta_{1} \mu-3 \delta^{2} \beta_{2} \eta_{2} \mu \beta_{1} \eta_{1}-4 \beta_{1} \eta_{1} \delta^{2} \mu \omega_{2} \eta_{2}-9(1- \\
& \text { a) } \omega_{1} \Lambda \delta^{3} \mu \eta_{2}+6(1-\alpha) \omega_{1} \Lambda \delta^{3} \mu \eta_{1}+4(1-\alpha) \omega_{1} \Lambda \delta^{3} \eta_{1} \eta_{2}+9 \omega_{1} \delta^{3} \eta_{2} \alpha \Lambda \mu+4 \omega_{1} \delta^{3} \eta_{2} \alpha \Lambda \eta_{1}+ \\
& 6 \delta^{3} \alpha \Lambda \mu \omega_{1} \eta_{1}+4 \delta^{3} \alpha \Lambda \mu \beta_{1} \eta_{1}+3 \delta^{3} \alpha \Lambda \eta_{1} \eta_{2} \mu+2 \delta^{3} \alpha \Lambda \mu \eta_{2} \beta_{1}+2 \delta^{3} \alpha \Lambda \mu \eta_{2} \beta_{1} \eta_{1}+2(1- \\
& \alpha) \Lambda \delta^{3} \eta_{1} \eta_{2} \mu+3(1-\alpha) \Lambda \delta^{3} \eta_{1} \beta_{1} \mu+2 \eta_{1} \beta_{1}(1-\alpha) \Lambda \delta^{3} \eta_{2}-9 \omega_{1} \delta^{2} \eta_{2} \beta_{2} \mu^{2}-3 \omega_{1} \delta^{2} \eta_{2}^{2} \beta_{2} \mu- \\
& 6 \delta^{2} \beta_{2} \mu^{2} \omega_{1} \eta_{1}-4 \delta^{2} \beta_{2} \mu^{2} \beta_{1} \eta_{1}-6 \delta^{2} \beta_{2} \mu^{2} \eta_{1} \eta_{2}-5 \delta^{2} \beta_{2} \mu^{2} \eta_{2} \beta_{1}-\delta^{2} \beta_{2} \mu \eta_{1}^{2} \omega_{1}- \\
& 9 \omega_{2} \beta_{1} \mu^{2} \delta^{2} \eta_{2}+3(1-\alpha) \Lambda \delta^{3} \mu^{2} \eta_{1}+(1-\alpha) \Lambda \delta^{3} \mu \eta_{1}^{2}+(1-\alpha) \Lambda \delta^{3} \eta_{1}^{2} \omega_{1}+(1-\alpha) \Lambda \delta^{3} \eta_{1}^{2} \beta_{1}+ \\
& \alpha \Lambda \delta^{3} \mu \eta_{1}^{2}+\delta^{3} \alpha \Lambda \eta_{1}^{2} \omega_{1}+\delta^{3} \alpha \Lambda \eta_{1}^{2} \beta_{1}+\delta^{3} \alpha \Lambda \eta_{2}^{2} \mu+6(1-\alpha) \omega_{1} \Lambda \delta^{3} \mu^{2}+3(1-\alpha) \omega_{1} \Lambda \delta^{3} \eta_{2}^{2}+ \\
& 3 \omega_{1} \delta^{3} \eta_{2}^{2} \alpha \Lambda+6 \delta^{3} \alpha \Lambda \mu^{2} \omega_{1}+6 \delta^{3} \alpha \Lambda \mu^{2} \eta_{2}+6 \delta^{3} \alpha \Lambda \mu^{2} \eta_{1}+3 \delta^{3} \alpha \Lambda \mu^{2} \beta_{1} \\
& r_{5}=-4 \delta \beta_{2} \mu^{5}-5 \omega_{2} \mu^{5} \delta-5 \omega_{1} \mu^{5} \delta-3 \mu^{4} \eta_{1}^{2} \delta-8 \mu^{5} \delta \eta_{1}-9 \mu^{4} \delta \eta_{2}^{2}-2 \mu^{3} \delta \eta_{2}^{3}-4 \beta_{1} \mu^{5} \delta- \\
& 12 \mu^{5} \delta \eta_{2}-3 \beta_{1} \eta_{1}^{2} \mu^{3} \delta-8 \omega_{2} \eta_{1} \mu^{4} \delta-3 \omega_{2} \eta_{1}^{2} \mu^{3} \delta-7 \beta_{1} \eta_{1} \mu^{4} \delta-9 \omega_{2} \eta_{2}^{2} \mu^{3} \delta-2 \omega_{2} \mu^{2} \delta \eta_{2}^{3}- \\
& 2 \beta_{2} \mu^{2} \eta_{2}^{3} \delta-2 \omega_{1} \mu^{2} \eta_{2}^{3} \delta-4 \mu^{3} \eta_{1} \eta_{2}^{2} \delta-\beta_{1} \mu^{2} \eta_{2}^{3} \delta-8 \omega_{1} \eta_{1} \mu^{4} \delta-9 \omega_{1} \mu^{3} \eta_{2}^{2} \delta-12 \eta_{1} \mu^{4} \delta \eta_{2}- \\
& 6 \beta_{1} \mu^{3} \eta_{2}^{2} \delta-3 \omega_{1} \eta_{1}^{2} \mu^{3} \delta-
\end{aligned}
$$




$$
\begin{aligned}
& 12 \omega_{2} \mu^{4} \delta \eta_{2}-4 \omega_{2} \beta_{1} \mu^{4} \delta-2 \mu^{3} \eta_{1}^{2} \delta \eta_{2}-12 \omega_{1} \mu^{4} \delta \eta_{2}-9 \beta_{1} \mu^{4} \delta \eta_{2}-10 \delta \beta_{2} \mu^{4} \eta_{2}-6 \delta \eta_{1} \beta_{2} \mu^{4}- \\
& 4 \delta \beta_{2} \mu^{4} \omega_{1}-3 \delta \beta_{2} \mu^{4} \beta_{1}-8 \delta \beta_{2} \mu^{3} \eta_{2}^{2}-2 \delta \beta_{2} \mu^{3} \eta_{1}^{2}+4 \delta^{2} \alpha \Lambda \mu^{4}-5 \mu^{6} \delta-2 \delta \beta_{2} \mu^{2} \eta_{1}^{2} \beta_{1}- \\
& 3 \delta \eta_{1} \eta_{2}^{2} \beta_{2} \mu^{2}-\delta \eta_{2} \eta_{1}^{2} \beta_{2} \mu^{2}-6 \beta_{1} \eta_{1} \delta \mu^{3} \omega_{2}-2 \beta_{1} \delta \eta_{1}^{2} \omega_{2} \mu^{2}-12 \omega_{1} \eta_{1} \delta \mu^{3} \eta_{2}-4 \omega_{1} \eta_{1} \mu^{2} \delta \eta_{2}^{2}- \\
& 12 \mu^{3} \omega_{2} \eta_{2} \eta_{1} \delta-9 \omega_{2} \beta_{1} \mu^{3} \delta \eta_{2}-10 \eta_{1} \beta_{1} \mu^{3} \eta_{2} \delta-6 \omega_{2} \beta_{1} \mu^{2} \eta_{2}^{2} \delta- \\
& 4 \omega_{2} \mu^{2} \eta_{2}^{2} \delta \eta_{1}-\beta_{2} \beta_{1} \mu \eta_{2}^{3} \delta-\omega_{2} \beta_{1} \mu \eta_{2}^{3} \delta-2 \omega_{1} \eta_{1}^{2} \mu^{2} \eta_{2} \delta-2 \omega_{2} \eta_{1}^{2} \mu^{2} \delta \eta_{2}-2 \beta_{1} \eta_{1}^{2} \mu^{2} \eta_{2} \delta+ \\
& 8(1-\alpha) \omega_{1} \Lambda \delta^{2} \mu \eta_{1} \eta_{2}+8 \omega_{1} \delta^{2} \eta_{2} \alpha \Lambda \eta_{1} \mu+5 \delta^{2} \alpha \Lambda \eta_{2} \beta_{1} \mu \eta_{1}+4(1-\alpha) \Lambda \delta^{2} \eta_{1} \eta_{2} \beta_{1} \mu- \\
& 8 \omega_{1} \delta \eta_{2} \beta_{2} \eta_{1} \mu^{2}-2 \omega_{1} \delta \eta_{2}^{2} \beta_{2} \eta_{1} \mu-7 \delta \beta_{2} \eta_{2} \mu^{2} \beta_{1} \eta_{1}-\delta \eta_{1}^{2} \beta_{2} \eta_{2} \omega_{1} \mu-2 \delta \eta_{1} \eta_{2}^{2} \beta_{2} \beta_{1} \mu- \\
& \delta \eta_{1}^{2} \eta_{2} \beta_{2} \beta_{1} \mu-8 \beta_{1} \eta_{1} \delta \mu^{2} \omega_{2} \eta_{2}-2 \beta_{1} \eta_{1} \delta \mu \omega_{2} \eta_{2}^{2}-\beta_{1} \eta_{1}^{2} \delta \omega_{2} \eta_{2}+\delta^{2} \alpha \Lambda \eta_{2}^{2} \beta_{1} \mu+(1- \\
& \alpha) \Lambda \delta^{2} \eta_{1}^{2} \eta_{2} \mu+ \\
& (1-\alpha) \Lambda \delta^{2} \eta_{1} \eta_{2}^{2} \mu+(1-\alpha) \Lambda \delta^{2} \eta_{2} \eta_{1}^{2} \omega_{1}+(1-\alpha) \Lambda \delta^{2} \eta_{2} \eta_{1}^{2} \beta_{1}+\delta^{2} \eta_{1}^{2} \eta_{2} \alpha \Lambda \mu+\delta^{2} \eta_{2}^{2} \eta_{1} \alpha \Lambda \mu+ \\
& \delta^{2} \eta_{1}^{2} \eta_{2} \alpha \Lambda \omega_{1}+\delta^{2} \eta_{1}^{2} \eta_{2} \alpha \Lambda \beta_{1}+\beta_{1} \eta_{1}(1-\alpha) \Lambda \delta^{2} \eta_{2}^{2}+\beta_{1} \delta^{2} \eta_{2}^{2} \eta_{1} \alpha \Lambda+9(1-\alpha) \omega_{1} \Lambda \delta^{2} \eta_{2} \mu^{2}+ \\
& 6(1-\alpha) \Lambda \delta^{2} \omega_{1} \eta_{2}^{2} \mu+6 \delta^{2} \omega_{1} \eta_{2}^{2} \alpha \Lambda \mu+6(1-\alpha) \Lambda \delta^{2} \omega_{1} \eta_{1} \mu^{2}+2(1-\alpha) \omega_{1} \Lambda \delta^{2} \eta_{2}^{2} \eta_{1}+ \\
& 9 \delta^{2} \omega_{1} \eta_{2} \alpha \Lambda \mu^{2}+2 \omega_{1} \delta^{2} \eta_{2}^{2} \alpha \Lambda \eta_{1}+6 \delta^{2} \alpha \Lambda \mu^{2} \omega_{1} \eta_{1}+5 \delta^{2} \alpha \Lambda \mu^{2} \beta_{1} \eta_{1}+6 \delta^{2} \alpha \Lambda \mu^{2} \eta_{2} \eta_{1}+ \\
& 4 \delta^{2} \alpha \Lambda \mu^{2} \eta_{2} \beta_{1}+2 \delta^{2} \alpha \Lambda \eta_{1}^{2} \mu \omega_{1}+2 \delta^{2} \alpha \Lambda \eta_{1}^{2} \mu \beta_{1}+4(1-\alpha) \Lambda \delta^{2} \eta_{1} \mu^{2} \eta_{2}+2(1- \\
& \alpha) \Lambda \delta^{2} \eta_{1}^{2} \mu \omega_{1}+3(1-\alpha) \Lambda \delta^{2} \eta_{1} \mu^{2} \beta_{1}+2(1-\alpha) \Lambda \delta^{2} \eta_{1}^{2} \mu \beta_{1}-9 \omega_{1} \delta \eta_{2} \beta_{2} \mu^{3}-6 \omega_{1} \delta \eta_{2}^{2} \beta_{2} \mu^{2}- \\
& \omega_{1} \delta \eta_{2}^{3} \beta_{2} \mu-6 \delta \beta_{2} \mu^{3} \omega_{1} \eta_{1}-7 \delta \beta_{2} \mu^{3} \beta_{1} \eta_{2}-5 \delta \beta_{2} \mu^{3} \beta_{1} \eta_{1}-9 \delta \beta_{2} \mu^{3} \eta_{2} \eta_{1}-5 \delta \beta_{2} \mu^{2} \eta_{2}^{2} \beta_{1}- \\
& 2 \delta \beta_{2} \mu^{2} \eta_{1}^{2} \omega_{1}-3 \beta_{1} \eta_{1} \mu^{2} \delta \eta_{2}^{2}+3(1-\alpha) \Lambda \delta^{2} \eta_{1} \mu^{3}+2(1-\alpha) \Lambda \delta^{2} \eta_{1}^{2} \mu^{2}+(1-\alpha) \omega_{1} \Lambda \delta^{2} \eta_{2}^{3}+ \\
& \omega_{1} \delta^{2} \eta_{2}^{3} \alpha \Lambda+4(1-\alpha) \omega_{1} \Lambda \delta^{2} \mu^{3}+6 \delta^{2} \alpha \Lambda \mu^{3} \eta_{1}+6 \delta^{2} \alpha \Lambda \mu^{3} \eta_{2}+4 \delta^{2} \alpha \Lambda \mu^{3} \omega_{1}+3 \delta^{2} \alpha \Lambda \mu^{3} \beta_{1}+ \\
& 2 \delta^{2} \alpha \Lambda \mu^{2} \eta_{2}^{2}+2 \delta^{2} \alpha \Lambda \mu^{2} \eta_{1}^{2} \\
& r_{6}=\mu\left(\mu+\eta_{2}\right)\left(\mu+\eta_{1}+\eta_{2}\right)\left(\Lambda \delta\left(\mu+\beta_{1}+\omega_{1}\right)\left(\alpha \mu+\eta_{1}\right)+\omega_{1}\left(\mu(1-\alpha)+\eta_{2}\right)\right)-\mu\left(\mu+\eta_{1}+\right. \\
& \left.\eta_{2}\right)\left(\left(\mu+\beta_{2}\right)\left(\mu+\beta_{1}+\omega_{1}\right)+\omega_{2}\left(\mu+\beta_{1}\right)\right)
\end{aligned}
$$

Berdasarkan sifat polinomial berderajat lima, persamaan (5) memiliki satu akar positif jika perkalian semua akarnya lebih dari nol. Selanjutnya diperoleh syarat untuk eksistensi $R^{*}$ yaitu $R_{0}>1$. Kompartemen $P_{R}^{*}, P_{C}^{*}, C^{*}$ akan eksis jika $R^{*}$ eksis. Oleh sebab itu, titik setimbang endemik eksis jika dan hanya jika $R_{0}>1$.

\section{$4 \quad$ Kestabilan Lokal Titik Setimbang}

Pada bagian ini akan dilakukan analisis kestabilan lokal pada kedua titik setimbang model, yaitu titik setimbang non endemik $E_{0}$ dan titik setimbang endemik $E_{1}$.

\subsection{Kestabilan Lokal Titik Setimbang Non Endemik}

Analisis kestabilan lokal pada titik setimbang non endemik diawali dengan mensubstitusikan nilai titik setimbang non endemik yaitu $E_{0}=\left(\frac{\Lambda}{\mu} \frac{\alpha \mu+\eta_{1}}{\mu+\eta_{2}+\eta_{1}}, \frac{\Lambda}{\mu} \frac{(1-\alpha) \mu+\eta_{2}}{\mu+\eta_{2}+\eta_{1}}, 0,0\right)$ ke dalam matriks Jacobian, sehingga diperoleh 


$$
J E_{0}=\left[\begin{array}{cccc}
-\left(\mu+\eta_{2}\right) & \eta_{1} & \beta_{2}-\delta \frac{\Lambda}{\mu} \frac{\alpha \mu+\eta_{1}}{\mu+\eta_{2}+\eta_{1}} & 0 \\
\eta_{2} & -\left(\mu+\eta_{1}\right) & -\delta \frac{\Lambda}{\mu} \frac{(1-\alpha) \mu+\eta_{2}}{\mu+\eta_{2}+\eta_{1}} & \beta_{1} \\
0 & 0 & -\left(\mu+\beta_{2}+\omega_{2}\right)+\delta \frac{\Lambda}{\mu} \frac{\alpha \mu+\eta_{1}}{\mu+\eta_{2}+\eta_{1}} & \omega_{1} \\
0 & 0 & \omega_{2}+\delta \frac{\Lambda}{\mu} \frac{(1-\alpha) \mu+\eta_{2}}{\mu+\eta_{2}+\eta_{1}} & -\left(\mu+\beta_{1}+\omega_{1}\right)
\end{array}\right]
$$

Berdasarkan matriks Jacobian $J_{E_{0}}$, dapat dibentuk persamaan karakteristik sebagai berikut:

$$
\operatorname{det}\left[\begin{array}{cccc}
-\left(\mu+\eta_{2}\right)-\lambda & \eta_{1} & \beta_{2}-\delta \frac{\Lambda}{\mu} \frac{\alpha \mu+\eta_{1}}{\mu+\eta_{2}+\eta_{1}} & 0 \\
\eta_{2} & -\left(\mu+\eta_{1}\right)-\lambda & -\delta \frac{\Lambda}{\mu} \frac{(1-\alpha) \mu+\eta_{2}}{\mu+\eta_{2}+\eta_{1}} & \beta_{1} \\
0 & 0 & -\left(\mu+\beta_{2}+\omega_{2}\right)+\delta \frac{\Lambda}{\mu} \frac{\alpha+\eta_{1}}{\mu+\eta_{2}+\eta_{1}}-\lambda & \omega_{1} \\
0 & 0 & \omega_{2}+\delta \frac{\Lambda}{\mu} \frac{(1-\alpha) \mu+\eta_{2}}{\mu+\eta_{2}+\eta_{1}} & -\left(\mu+\beta_{1}+\omega_{1}\right)-\lambda
\end{array}\right]=0
$$

atau diperoleh bentuk yang ekivalen sebagai berikut

$$
\left(\lambda^{2}+\lambda A_{1}+A_{2}\right)\left(\lambda^{2}+\lambda B_{1}+B_{2}\right)=0
$$

dengan

$A_{1}=2 \mu+\eta_{2}+\eta_{1}$

$A_{2}=\mu^{2}+\mu \eta_{1}+\eta_{2} \mu$

$B_{1}=\left(2 \mu+\beta_{2}+\omega_{2}\right)+\left(\beta_{1}+\omega_{1}\right)-\delta \frac{\Lambda}{\mu} \frac{\alpha \mu+\eta_{1}}{\mu+\eta_{2}+\eta_{1}}$

$B_{2}=\left(\mu+\beta_{2}\right)\left(\mu+\beta_{1}+\omega_{1}\right)+\omega_{2}\left(\mu+\beta_{1}\right)-\left(\mu+\beta_{1}+\omega_{1}\right) \delta \frac{\Lambda}{\mu} \frac{\alpha \mu+\eta_{1}}{\mu+\eta_{2}+\eta_{1}}-\omega_{1} \delta \frac{\Lambda}{\mu} \frac{(1-\alpha) \mu+\eta_{2}}{\mu+\eta_{2}+\eta_{1}}$

Titik setimbang non endemik akan stabil asimtotis jika dan hanya jika persamaan karakteristik (6a) memiliki akar-akar bagian real negatif. Hal tersebut dapat diselesaikan dengan menggunakan kriteria Routh-Hurwitz. Metode ini memperhatikan koefisienkoefisien dari persamaan karakteristik tanpa menghitung persamaan karakteristik secara langsung. Selanjutnya akan dicari nilai eign dari persamaan (6a). Pandang persamaan berikut:

$$
\left(\lambda^{2}+\lambda A_{1}+A_{2}\right)=0
$$


Berdasarkan kriteria Routh-Hurwitz persamaan (6b) akan memiliki akar - akar bagian real negatif jika dan hanya jika $A_{1}, A_{2}>0$. Jelas bahwa $A_{1}, A_{2}>0$ karena semua parameter bernilai positif.

Pandang persamaan berikut:

$$
\left(\lambda^{2}+\lambda B_{1}+B_{2}\right)=0
$$

Berdasarkan kriteria Routh-Hurwitz persamaan (6c) akan memiliki akar - akar bagian real negatif jika dan hanya jika $B_{1}, B_{2}>0$. Selanjutnya agar $B_{1}>0$ diperoleh syarat yaitu $\frac{J}{K} \mathrm{R}_{0}<1$ dengan $J=\left(\alpha \mu+\eta_{1}\right)\left(\left(\mu+\beta_{2}\right)\left(\mu+\beta_{1}+\omega_{1}\right)+\omega_{2}\left(\mu+\beta_{1}\right)\right)$ dan $K=$ $\left(\left(2 \mu+\beta_{2}+\omega_{2}\right)+\left(\beta_{1}+\omega_{1}\right)\right)\left(\left(\alpha \mu+\eta_{1}\right)\left(\mu+\beta_{1}+\omega_{1}\right)+\omega_{1}\left[(1-\alpha) \mu+\eta_{2}\right]\right)$ sedangkan agar $B_{2}>0$ diperoleh syarat $\mathrm{R}_{0}<1$. Selanjutnya dengan menguraikan parameter dalam $J$ dan $K$ serta membandingkan nilainya diperoleh $\frac{J}{K}<1$. Dengan demikian dapat dituliskan bahwa $\frac{J}{K} \mathrm{R}_{0}<\mathrm{R}_{0}$. Oleh karena itu syarat kestabilan titik setimbang non endemik hanya bergantung pada $\mathrm{R}_{0}<1$. Maka dapat disimpulkan bahwa titik setimbang non endemik stabil asimtotis jika dan hanya jika $\mathrm{R}_{0}<1$.

\subsection{Kestabilan Lokal Titik Setimbang Endemik}

Langkah pertama untuk menentukan kestabilan titik setimbang endemik yaitu dengan mensubstitusikan titik setimbang endemik $E_{1}=\left(P_{R}^{*}, P_{C}^{*}, R^{*}, C^{*}\right)$ pada matriks Jacobian, sehingga diperoleh :

$$
J E_{1}=\left[\begin{array}{cccc}
-y_{1} & \eta_{1} & \beta_{2}-y_{2} & 0 \\
\eta_{2} & -y_{3} & -y_{4} & \beta_{1} \\
\delta R^{*} & 0 & -d_{3}+y_{2} & \omega_{1} \\
0 & \delta R^{*} & \omega_{2}+y_{4} & -d_{4}
\end{array}\right]
$$

dengan

$$
\begin{aligned}
& y_{1}=d_{1}+\delta R^{*} \\
& y_{2}=\delta \frac{d_{5}}{d_{7}} \\
& y_{3}=d_{2}+\delta R^{*} \\
& y_{4}=\delta \frac{d_{6}}{d_{8}} \\
& d_{1}=\mu+\eta_{2} \\
& d_{2}=\mu+\eta_{1} \\
& d_{3}=\mu+\beta_{2}+\omega_{2} \\
& d_{4}=\mu+\beta_{1}+\omega_{1}
\end{aligned}
$$


$d_{5}=\left(\alpha \Lambda+\beta_{2} R^{*}\right)\left[\mu\left(\mu+\eta_{2}+\delta R^{*}\right)+\eta_{1}\left(\mu+\delta R^{*}\right)+\delta R^{*}\left(\mu+\eta_{2}+\delta R^{*}\right)\right]+(1-\alpha) \Lambda \eta_{1}\left(\mu+\eta_{2}+\right.$

$\left.\delta R^{*}\right)+\eta_{1} \beta_{1} C^{*}\left(\mu+\eta_{2}+\delta R^{*}\right)+\eta_{1} \eta_{2} \alpha \Lambda+\eta_{1} \eta_{2} \beta_{2} R^{*}$

$d_{6}=(1-\alpha) \Lambda\left(\mu+\eta_{2}+\delta R^{*}\right)+\beta_{1} C^{*}\left(\mu+\eta_{2}+\delta R^{*}\right)+\eta_{2} \alpha \Lambda+\eta_{2} \beta_{2} R^{*}$

$d_{7}=\left[\mu\left(\mu+\eta_{2}+\delta R^{*}\right)+\eta_{1}\left(\mu+\delta R^{*}\right)+\delta R^{*}\left(\mu+\eta_{2}+\delta R^{*}\right)\right]\left(\mu+\eta_{2}+\delta R^{*}\right)$

$d_{8}=\mu\left(\mu+\eta_{2}+\delta R^{*}\right)+\eta_{1}\left(\mu+\delta R^{*}\right)+\delta R^{*}\left(\mu+\eta_{2}+\delta R^{*}\right)$

Berdasarkan matriks Jacobian di sekitar titik setimbang endemik $E_{1}$, akan ditentukan nilai eigennya dengan menggunakan $\operatorname{det}\left(J_{E_{1}}-\lambda I\right)=0$, yaitu

$$
\operatorname{det}\left[\begin{array}{cccc}
-y_{1}-\lambda & \eta_{1} & \beta_{2}-y_{2} & 0 \\
\eta_{2} & -y_{3}-\lambda & -y_{4} & \beta_{1} \\
\delta R^{*} & 0 & -d_{3}+y_{2}-\lambda & \omega_{1} \\
0 & \delta R^{*} & \omega_{2}+y_{4} & -d_{4}-\lambda
\end{array}\right]=0
$$

Dari sini, diperoleh persamaan karakteristik sebagai berikut:

$$
\lambda^{4}+\lambda^{3} G_{1}+\lambda^{2} G_{2}+\lambda G_{3}+G_{4}=0
$$

Karena nilai $G_{1}, G_{2}, G_{3}$ dan $G_{4}$ mengandung banyak parameter yang sulit disederhanakan, maka Penentuan akar-akar persamaan karakteristik pada persamaan (7) sulit dilakukan secara analitik. Oleh sebab itu, titik setimbang endemik akan dianalisis melalui simulasi numerik menggunakan bidang fase.

Simulasi ini dilakukan dengan memberikan nilai parameter dan tiga nilai awal yang berbeda untuk setiap populasi $\left(P_{R}(0), P_{C}(0), R(0), C(0)\right)$. Hal ini bertujuan untuk mengetahui solusi dari setiap nilai awal yang diberikan menuju ke satu titik atau tidak. Adapun waktu yang digunakan pada simulasi ini adalah saat $t=0$ sampai $t=100$ tahun. Adapun nilai awal dan nilai parameter disajikan pada Tabel 2 dan Tabel 3.

Tabel 2 Nilai Parameter Model Matematika Penyalahgunaan Narkoba dengan Memperhatikan Tipe Perawatan beserta Tingkat Resiko

\begin{tabular}{|c|c|c|c|}
\hline Parameter & Nilai & Satuan & Sumber \\
\hline$\wedge$ & 244.2 & $\frac{\text { orang }}{\text { tahun }}$ & {$[3]$} \\
\hline$\alpha$ & 0.01 & - & {$[3]$} \\
\hline$\mu$ & 0.01 & $\frac{1}{\text { tahun }}$ & {$[3]$} \\
\hline$\eta_{1}$ & 0.0002 & $\frac{1}{\text { tahun }}$ & {$[3]$} \\
\hline$\eta_{2}$ & 0.0002 & $\frac{1}{\text { tahun }}$ & {$[3]$} \\
\hline
\end{tabular}




\begin{tabular}{|c|c|c|c|}
\hline Parameter & Nilai & Satuan & Sumber \\
\hline$\delta$ & 0.002 & $\frac{1}{\text { tahun }}$ & Asumsi \\
\hline$\omega_{1}$ & $\frac{0.004}{2200}$ & $\frac{1}{\text { tahun }}$ & {$[3]$} \\
\hline$\omega_{2}$ & 0.0002 & $\frac{1}{\text { tahun }}$ & {$[3]$} \\
\hline$\beta_{1}$ & 0.18 & $\frac{1}{\text { tahun }}$ & {$[3]$} \\
\hline$\beta_{2}$ & 0.18 & $\frac{1}{\text { tahun }}$ & {$[3]$} \\
\hline
\end{tabular}

Tabel 3 Nilai Awal Bidang Fase Titik Setimbang Endemik $E_{1}$

\begin{tabular}{|c|c|c|c|c|c|}
\hline Nilai awal & $\boldsymbol{P}_{\boldsymbol{R}}(\mathbf{0})$ & $\boldsymbol{P}_{\boldsymbol{C}}(\mathbf{0})$ & $\boldsymbol{R}(\mathbf{0})$ & $\boldsymbol{C}(\mathbf{0})$ & Warna \\
\hline 1 & 90 & 200 & 250 & 300 & Hijau \\
\hline 2 & 100 & 350 & 450 & 500 & Biru \\
\hline 3 & 200 & 305 & 350 & 400 & Merah \\
\hline
\end{tabular}

Hasil simulasi bidang fase pada titik setimbang endemik model matematika penyalahgunaan narkoba dengan memperhatikan tipe perawatan beserta tingkat resiko ditunjukkan pada Gambar 2 berikut: 


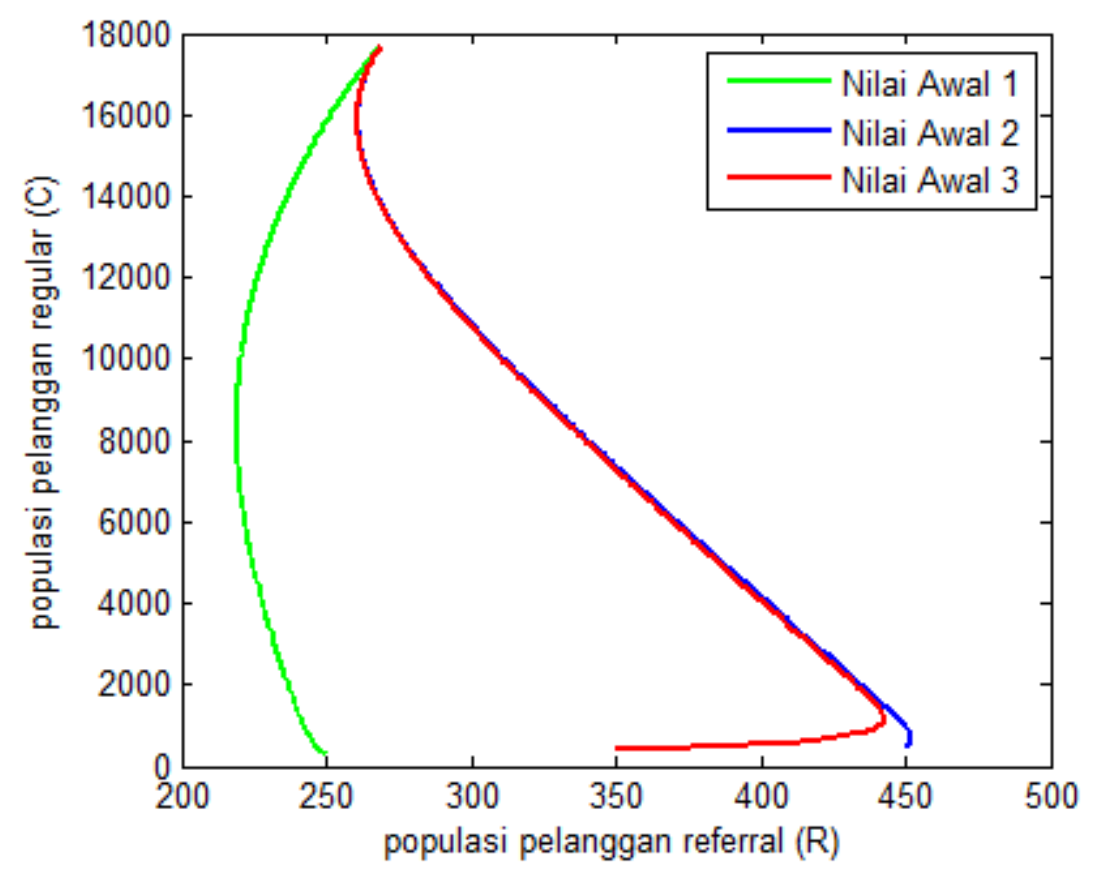

Gambar 2 Grafik Bidang Fase Populasi $R-C$

Berdasarkan Gambar 2 terlihat bahwa untuk masing-masing nilai awal, jumlah kedua populasi menuju ke satu titik yaitu $(R, C)=(268,17650)$. Hal ini berarti solusi dari setiap subpopulasi pada model bergerak menuju ke titik setimbang endemik yaitu $E_{1}=$ $\left(P_{R}^{*}, P_{C}^{*}, R^{*}, C^{*}\right)=(95 ; 6256 ; 268 ; 17650)$ Selain itu, didapatkan juga nilai $R_{0}=$ $7.4096>1$. Karena pada Gambar 2 menunjukkan grafik bergerak menuju satu titik yaitu titik setimbang endemik serta diperoleh nilai $R_{0}>1$, maka titik setimbang endemik $E_{1}$ cenderung stabil asimtotis jika memenuhi $R_{0}>1$. Ini berarti jika syarat terpenuhi, maka terjadi penyebaran pengaruh pelanggan referral terhadap pelanggan potensial untuk menjadi pelanggan referral atau regular.

\section{$5 \quad$ Analisis Sensitivitas Parameter}

Pada saat menganalisis syarat kestabilan tentunya terdapat beberapa parameter yang berpengaruh cukup besar. Analisis sensitivitas bertujuan untuk menentukan parameter yang memiliki pengaruh besar pada syarat kestabilan dari titik setimbang non endemik maupun endemik. Hal tersebut dapat diketahui melalui indeks sensitivitas $\left(e_{m}\right)$ dari masing-masing parameter. Adapun indeks sensitivitas parameter dirumuskan sebagai berikut [7]:

$$
e_{m}=\left(\frac{\partial R_{0}}{\partial m}\right) \frac{m}{R_{0}}
$$


dengan :

$m$ : parameter yang akan dianalisis

$e_{m}:$ indeks sensitivitas parameter $m$.

Pada penelitian ini, $R_{0}$ yang digunakan adalah sebagai berikut:

$$
R_{0}=\frac{\Lambda \delta\left(\left(\alpha \mu+\eta_{1}\right)\left(\mu+\beta_{1}+\omega_{1}\right)+\omega_{1}\left[(1-\alpha) \mu+\eta_{2}\right]\right)}{\mu\left(\mu+\eta_{2}+\eta_{1}\right)\left(\left(\mu+\beta_{2}\right)\left(\mu+\beta_{1}+\omega_{1}\right)+\omega_{2}\left(\mu+\beta_{1}\right)\right)}
$$

Terdapat 10 parameter yang mempengaruhi $R_{0}$ diantaranya $\Lambda, \delta, \alpha, \mu, \eta_{1}, \beta_{1}, \omega_{1}, \eta_{2}, \beta_{2}$, dan $\omega_{2}$. Berikut diberikan contoh perhitungan indeks sensitivitas untuk parameter $\Lambda$.

$e_{\Lambda}=\left(\frac{\partial R_{0}}{\partial \Lambda}\right) \frac{\Lambda}{R_{0}}=\frac{\delta\left(\left(\alpha \mu+\eta_{1}\right)\left(\mu+\beta_{1}+\omega_{1}\right)+\omega_{1}\left[(1-\alpha) \mu+\eta_{2}\right]\right)}{\mu\left(\mu+\eta_{2}+\eta_{1}\right)\left(\left(\mu+\beta_{2}\right)\left(\mu+\beta_{1}+\omega_{1}\right)+\omega_{2}\left(\mu+\beta_{1}\right)\right)} \frac{\Lambda \mu\left(\mu+\eta_{2}+\eta_{1}\right)\left(\left(\mu+\beta_{2}\right)\left(\mu+\beta_{1}+\omega_{1}\right)+\omega_{2}\left(\mu+\beta_{1}\right)\right)}{\Lambda \delta\left(\left(\alpha \mu+\eta_{1}\right)\left(\mu+\beta_{1}+\omega_{1}\right)+\omega_{1}\left[(1-\alpha) \mu+\eta_{2}\right]\right)}=1$.

Hasil perhitungan indeks sensitivitas parameter model matematika dinamika pelanggan berdasarkan kebijakan pemasaran dapat dilihat pada Tabel 4 berikut :

Tabel 4 Hasil Perhitungan Indeks Sensitivitas Parameter

\begin{tabular}{|c|c|}
\hline Parameter & Indeks Sensitivitas \\
\hline$\Lambda$ & 1 \\
\hline$\delta$ & 1 \\
\hline$\alpha$ & 0.33 \\
\hline$\mu$ & -1.68 \\
\hline$\eta_{1}$ & 0.64 \\
\hline$\beta_{1}$ & -0.0003 \\
\hline$\omega_{1}$ & 0.00032 \\
\hline$\eta_{2}$ & -0.019 \\
\hline$\beta_{2}$ & -0.95 \\
\hline$\omega_{2}$ & -0.001 \\
\hline
\end{tabular}

Berdasarkan Tabel 4, untuk indeks sensitivitas yang bernilai positif, jika nilai parameter dinaikkan maka nilai $R_{0}$ akan bertambah. Sebaliknya, untuk indeks sensitivitas yang bernilai negatif, jika nilai parameter dinaikkan maka nilai $R_{0}$ akan berkurang. Sebagai contoh, jika parameter $\delta$ bertambah sebesar $10 \%$, maka nilai $R_{0}$ juga akan bertambah $10 \%$. Namun, ketika parameter $\mu$ bertambah sebesar $10 \%$, maka nilai $R_{0}$ akan berkurang sebesar $9.4 \%$. Analisis tersebut berlaku pula untuk parameter $\Lambda, \alpha, \beta_{1}, \omega_{1}, \eta_{2}, \beta_{2}, \eta_{1}$, dan $\omega_{2}$. Dari penjelasan analisis tersebut, parameter yang memiliki pengaruh besar dalam model adalah $\Lambda, \delta$, dan $\mu$. Namun, karena parameter laju rekruitmen pelanggan $(\Lambda)$ tidak dapat dikontrol, maka salah satu parameter yang berpengaruh dan dapat dikontrol adalah $\delta$ dan $\mu$. 
Selanjutnya, akan disimulasikan sensitivitas parameter $\delta$ dan $\mu$ terhadap $R_{0}$ yang masing - masing merupakan laju perubahan pelanggan potensial ke pelanggan referral atau regular karena pengaruh pelanggan referral dan laju hilangnya pelanggan karena kematian, emigrasi, dan kehilangan kepercayaan terhadap suatu produk. Pada simulasi ini dipilih nilai $\mu=0.01, \mu=0.02, \mu=0.03$, dengan $\delta$ berada pada selang $0,1 \leq \delta \leq$ 0,9 .. Berikut adalah hasil simulasi berupa grafik sensitivitas $\delta$ dan $\mu$ terhadap $R_{0}$ dapat dilihat pada Gambar 3.

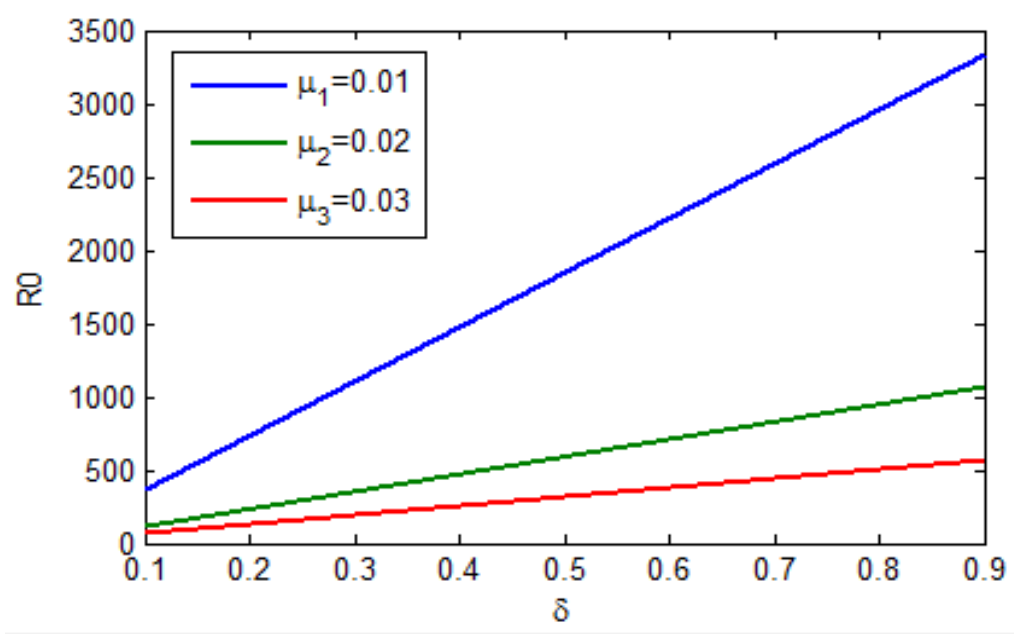

Gambar 3 Sensitivitas $\delta$ Terhadap $R_{0}$ dengan Nilai $\mu$ yang Berbeda

Berdasarkan Gambar 3, terlihat bahwa untuk ketiga nilai $\mu$ yang berbeda, semakin besar nilai $\mu$ maka semakin kecil nilai $R_{0}$. Selain itu, semakin besar nilai $\delta$ maka semakin besar pula nilai $R_{0}$. Hal ini menunjukkan bahwa indeks sensitivitas $\mu$ yang bernilai negatif mengakibatkan jika nilai $\mu$ dinaikkan maka nilai $R_{0}$ turun, sedangkan indeks sensitivitas $\delta$ yang bernilai positif mengakibatkan jika nilai $\delta$ dinaikkan maka nilai $R_{0}$ juga naik.

\section{Analisis Masalah Kontrol Optimal}

Salah satu tujuan penelitian ini adalah menganalisis kontrol optimal untuk model matematika dinamika pelanggan berdasarkan kebijakan pemasaran. Sebelumnya, terlebih dahulu dikontruksi bentuk kontrol optimal untuk model matematika yang dibahas. Kontrol optimal yang ditambahkan pada model untuk penelitian ini adalah upaya pengiklanan suatu produk melalui word of mouth..

Berikut diberikan model matematika dinamika pelanggan berdasarkan kebijakan pemasaran dengan adanya penambahan variabel kontrol:

$$
\frac{d P_{R}}{d t}=\alpha \Lambda+\beta_{2} R+\eta_{1} P_{C}-\left(\mu+\eta_{2}\right) P_{R}-(\delta+u \gamma) R P_{R}
$$




$$
\begin{aligned}
& \frac{d P_{C}}{d t}=(1-\alpha) \Lambda+\beta_{1} C+\eta_{2} P_{R}-\left(\mu+\eta_{1}\right) P_{C}-\delta R P_{C} \\
& \frac{d R}{d t}=\omega_{1} C-\left(\mu+\beta_{2}+\omega_{2}\right) R+(\delta+u \gamma) R P_{R} \\
& \frac{d C}{d t}=\omega_{2} R-\left(\mu+\beta_{1}+\omega_{1}\right) C+\delta R P_{C}
\end{aligned}
$$

Dengan $u(t)$ merupakan upaya pengiklanan suatu produk melalui word of mouth pada saat $t$. Variabel kontrol $u$ terdapat pada persamaan (8a) dan (8c). Pemberian variabel kontrol ini bertujuan untuk menambah populasi pelanggan referral dan pelanggan regular serta meminimumkan biaya yang dikeluarkan untuk upaya tersebut. Untuk mencapai tujuan tersebut digunakanlah metode Prinsip Maksimum Pontryagin. Dengan demikian dapat dibentuk fungsi ongkos atau indeks performansi sebagai berikut :

$$
\max J=\int_{t_{0}}^{t_{f}} R+C-\frac{1}{2} \theta u^{2} d t
$$

Dengan koefisien $\theta$ adalah konstanta pembobot berupa biaya yang harus dikeluarkan untuk pengiklanan word of mouth. Batas kontrol optimal berada pada $0 \leq u(t) \leq 1,0 \leq$ $t \leq t_{f}$ serta $t_{f}$ merupakan waktu akhir pengamatan.

\subsection{Penyelesaian Kontrol Optimal}

Berdasarkan Prinsip Maksimum Pontryagin, langkah pertama yang dilakukan adalah membentuk fungsi Hamiltonian pada model sebagai berikut:

$$
H=R+C-\frac{1}{2} \theta u^{2}+\psi^{\prime}(t) f(x(t), u(t), t)
$$

dengan $f(x(t), u(t), t)$ adalah ruas kanan dari model yang disertai penambahan variabel kontrol. Sedangkan $\psi(t)$ merupakan pengali Lagrange atau variabel co-state dan $\psi^{\prime}(t)$ adalah transpose dari $\psi(t)$ sehingga dapat dituliskan sebagai berikut :

$\psi(t)=\left(\begin{array}{l}\psi_{1} \\ \psi_{2} \\ \psi_{3} \\ \psi_{4}\end{array}\right)$ dan $\psi^{\prime}(t)=\left(\begin{array}{llll}\psi_{1} & \psi_{2} & \psi_{3} & \psi_{4}\end{array}\right)$.

Fungsi Hamiltonian tersebut dapat diuraikan sebagai berikut:

$$
\begin{aligned}
H= & R+C-\frac{1}{2} \theta u^{2}+\psi_{1}\left[\alpha \Lambda+\beta_{2} R+\eta_{1} P_{C}-\left(\mu+\eta_{2}\right) P_{R}-(\delta+u \gamma) R P_{R}\right]+ \\
& \psi_{2}\left[(1-\alpha) \Lambda+\beta_{1} C+\eta_{2} P_{R}-\left(\mu+\eta_{1}\right) P_{C}-\delta R P_{C}\right]+\psi_{3}\left[\omega_{1} C-\left(\mu+\beta_{2}+\right.\right. \\
& \left.\left.\omega_{2}\right) R+(\delta+u \gamma) R P_{R}\right]+\psi_{4}\left[\omega_{2} R-\left(\mu+\beta_{1}+\omega_{1}\right) C+\delta R P_{C}\right]
\end{aligned}
$$


Selanjutnya untuk memperoleh $u$ yang optimal, maka fungsi Hamiltonian harus memenuhi kondisi stasioner yaitu $\frac{\partial H}{\partial u}=0$ dengan uraian berikut :

$$
\begin{aligned}
& \frac{\partial H}{\partial u}=0 \\
& \Leftrightarrow-\theta u-\psi_{1} \gamma R P_{R}+\psi_{3} \gamma R P_{R}=0 \\
& \Leftrightarrow \theta u=-\psi_{1} \gamma R P_{R}+\psi_{3} \gamma R P_{R} \\
& \Leftrightarrow u=\frac{\psi_{3} \gamma R P_{R}-\psi_{1} \gamma R P_{R}}{\theta}
\end{aligned}
$$

Batas kontrol optimal berada pada $0 \leq u(t) \leq 1$, sehingga diperoleh beberapa kemungkinan nilai $u$ yang dapat dituliskan sebagai berikut :

$$
u^{*}=\left\{\begin{array}{cl}
0 & \text { untuk } u^{*} \leq 0 \\
\frac{\psi_{3} \gamma R P_{R}-\psi_{1} \gamma R P_{R}}{\theta} & \text { untuk } 0<u^{*}<1 \\
1 & \text { untuk } u^{*} \geq 1
\end{array}\right.
$$

Berdasarkan kemungkinan diatas, maka diperoleh nilai $u^{*}$ yang optimal sebagai berikut :

$$
u^{*}=\min \left(1, \max \left(0, \frac{\psi_{3} \gamma R P_{R}-\psi_{1} \gamma R P_{R}}{\theta}\right)\right)
$$

Dari persamaan (8f) diketahui bahwa nilai kontrol $u$ bergantung pada variavel state dan co-state, sehingga perlu adanya penyelesaian persamaan state dan persamaan co-state untuk memperoleh variabel tersebut.

Berikut adalah penyelesaian persamaan state yang diperoleh dari $\frac{\partial H}{\partial \psi}$ :

$$
\begin{aligned}
& \dot{P_{R}}=\frac{\partial H}{\partial \psi_{1}}=\alpha \Lambda+\beta_{2} R+\eta_{1} P_{C}-\left(\mu+\eta_{2}\right) P_{R}-(\delta+u \gamma) R P_{R} \\
& \dot{P_{C}}=\frac{\partial H}{\partial \psi_{2}}=(1-\alpha) \Lambda+\beta_{1} C+\eta_{2} P_{R}-\left(\mu+\eta_{1}\right) P_{C}-\delta R P_{C} \\
& \dot{R}=\frac{\partial H}{\partial \psi_{3}}=\omega_{1} C-\left(\mu+\beta_{2}+\omega_{2}\right) R+(\delta+u \gamma) R P_{R} \\
& \dot{C}=\frac{\partial H}{\partial \psi_{4}}=\omega_{2} R-\left(\mu+\beta_{1}+\omega_{1}\right) C+\delta R P_{C} .
\end{aligned}
$$

Berikut ini adalah penyelesaian persamaan co-state yang diperoleh dari $-\frac{\partial H}{\partial x}$ :

$\dot{\psi_{1}}=-\frac{\partial H}{\partial P_{R}}=-\left[-\psi_{1}\left(\mu+\eta_{2}\right)-\psi_{1}(\delta+u \gamma) R+\psi_{2} \eta_{2}+\psi_{3}(\delta+u \gamma) R\right]$ 


$$
\begin{aligned}
\dot{\psi_{2}}= & -\frac{\partial H}{\partial P_{C}}=-\left[\psi_{1} \eta_{1}-\psi_{2}\left(\mu+\eta_{1}\right)-\psi_{2} \delta R+\psi_{4} \delta R\right] \\
\dot{\psi_{3}}= & -\frac{\partial H}{\partial R}=-\left[1+\psi_{1} \beta_{2}-\psi_{1}(\delta+u \gamma) P_{R}-\psi_{2} \delta P_{C}-\psi_{3}\left(\mu+\beta_{2}+\omega_{2}\right)+\right. \\
& \left.\psi_{3}(\delta+u \gamma) P_{R}+\psi_{4} \omega_{2} R+\psi_{4} \delta P_{C}\right] \\
\dot{\psi_{4}}= & -\frac{\partial H}{\partial C}=-\left[1+\psi_{2} \beta_{1}+\psi_{3} \omega_{1}-\psi_{4}\left(\mu+\beta_{1}+\omega_{1}\right)\right]
\end{aligned}
$$

Dengan syarat akhir variabel co-state $\psi_{i}\left(t_{f}\right)=0, i=1,2,3,4$.

Dari persamaan state dan co-state akan diperoleh nilai variabel state dan co-state yang selanjutnya disubstitusikan pengontrol $u^{*}$. Berikutnya mensubstitusikan persamaan (8f) ke dalam persamaan state untuk memperoleh bentuk solusi yang optimal sebagai berikut:

$$
\begin{aligned}
\dot{P_{R}}= & \alpha \Lambda+\beta_{2} R+\eta_{1} P_{C}-\left(\mu+\eta_{2}\right) P_{R}-(\delta+ \\
& \left.\min \left(1, \max \left(0, \frac{\psi_{3} \gamma R P_{R}-\psi_{1} \gamma R P_{R}}{\theta}\right)\right) \gamma\right) R P_{R} \\
\dot{P_{C}=} & (1-\alpha) \Lambda+\beta_{1} C+\eta_{2} P_{R}-\left(\mu+\eta_{1}\right) P_{C}-\delta R P_{C} \\
\dot{R}= & \omega_{1} C-\left(\mu+\beta_{2}+\omega_{2}\right) R+\left(\delta+\min \left(1, \max \left(0, \frac{\psi_{3} \gamma R P_{R}-\psi_{1} \gamma R P_{R}}{\theta}\right)\right) \gamma\right) R P_{R} \\
\dot{C}= & \omega_{2} R-\left(\mu+\beta_{1}+\omega_{1}\right) C+\delta R P_{C}
\end{aligned}
$$

Berdasarkan penjelasan diatas untuk memperoleh nilai $P_{R}, P_{C}, R, C$ dari bentuk $u^{*}$ yang optimal, harus ditentukan penyelesaian persamaan state dan co-state. Namun persamaan tersebut berbentuk non linier yang sulit diselesaikan secara analitik, sehingga akan diselesaikan secara numerik.

\subsection{Simulasi}

Penyelesaian secara numerik untuk kontrol masalah optimal dapat dilakukan dengan mensimulasikan permasalahan kontrol optimal menggunakan program DOTcvp pada software MATLAB. Simulasi ini juga bertujuan untuk mengetahui pengaruh pemberian upaya pengiklanan word of mouth terhadap populasi yang akan dimaksimalkan. Pada program DOTcvp persamaan state didefinisikan sebagai $P_{R}=y(1), P_{C}=y(2), R=$ $y(3), C=y(4)$, sedangkan indeks performansi didefinisikan sebagai state baru yaitu $y(5)$ dan variabel kontrol $u(1)$.

Pada simulasi numerik ini diberikan nilai awal untuk semua populasi yaitu $P_{R}(0)=$ $200, P_{C}(0)=22000, R(0)=20, C(0)=2200$. Simulasi ini dilakukan untuk $t=0$ sampai $t=100$ tahun. Nilai parameter yang digunakan merujuk pada Tabel 4 . konstanta pembobot untuk upaya pengiklanan word of mouth adalah $\theta=10$. 
Simulasi kontrol optimal ini dilakukan dengan mengamati populasi pelanggan referral dan pelanggan regular untuk dibandingkan dengan simulasi pada saat belum diberi upaya pengiklanan word of mouth. Karena pada skripsi ini hanya terdapat satu penambahan variabel kontrol, maka simulasi dilakukan dengan satu skenario yaitu saat ada upaya pengiklanan word of mouth $(u \neq 0)$.

Berikut adalah hasil simulasi perbandingan populasi pelanggan referral tanpa adanya variabel kontrol dan dengan adanya variabel kontrol.

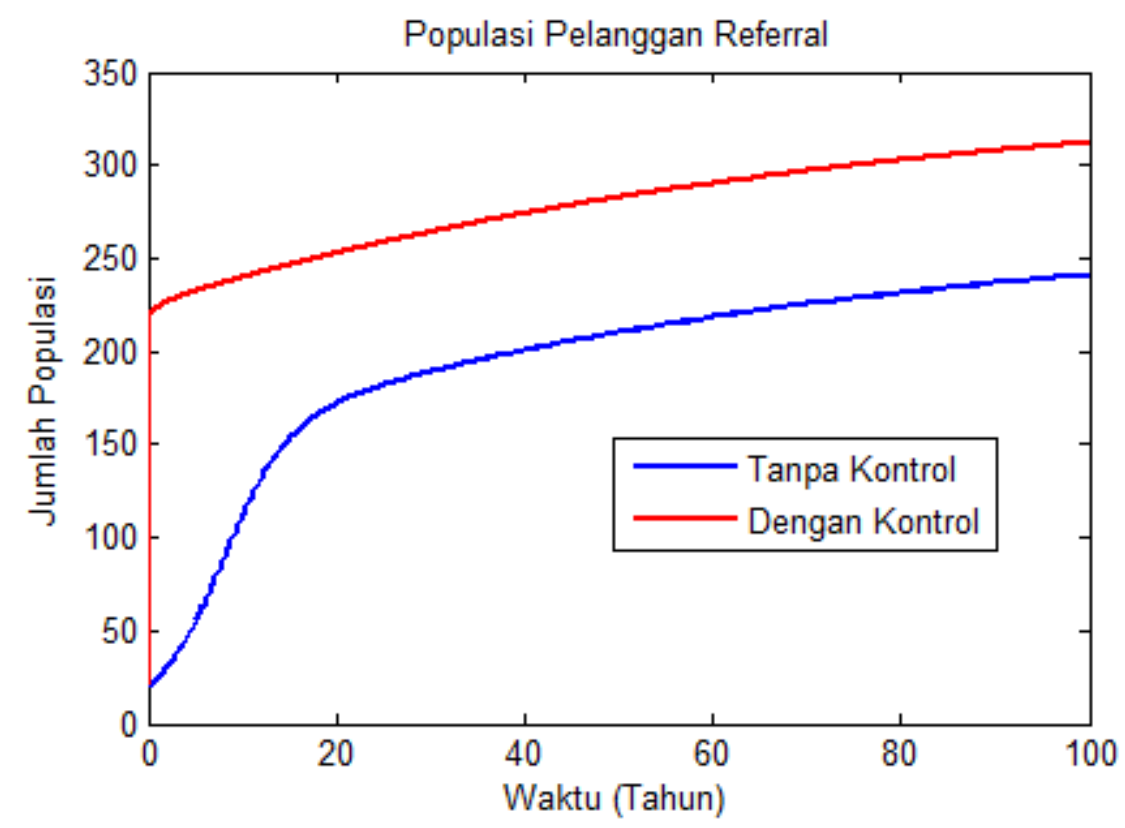

Gambar 4 Simulasi Perbandingan Jumlah Pelanggan Referral $(R)$

Berdasarkan Gambar 4 terlihat bahwa terdapat perbedaan antara jumlah populasi tanpa diberi upaya kontrol dan jumlah populasi setelah diberi upaya kontrol. Jumlah populasi tanpa diberi kontrol naik signifikan hingga tahun ke-20 kemudian naik secara bertahap sampai akhir pengamatan. Namun setelah diberi upaya pengiklanan word of mouth, pada awal pengamatan jumlah populasi pelanggan referral naik secara signifikan melebihi jumlah populasi pelanggan referral sebelum diberi upaya kontrol. Setelah itu pada awal pengamatan pula populasi naik secara bertahap sampai akhir pengamatan. Hal ini menunjukkan bahwa upaya pengiklanan word of mouth memberikan efek untuk meningkatkan jumlah populasi pelanggan referral sesuai dengan tujuan pemberian kontrol optimal. Berikut ini diberikan tabel perbandingan jumlah populasi pelanggan referral tanpa dan dengan adanya penambahan variabel kontrol yang diamati pada akhir pengamatan : 
Tabel 5 Perbandingan Populasi Pelanggan Referral $(R)$ Pada Akhir Pengamatan

\begin{tabular}{|c|c|}
\hline Skenario & Jumlah Populasi $\boldsymbol{R}$ \\
\hline Tanpa Kontrol & 241 \\
\hline Dengan Kontrol & 312 \\
\hline
\end{tabular}

Berdasarkan Tabel 5 terlihat bahwa kedua skenario memiliki perbedaan jumlah populasi saat akhir pengamatan. Hal ini mempertegas bahwa pemberian kontrol memberikan efek untuk memaksimalkan jumlah pelanggan referral.

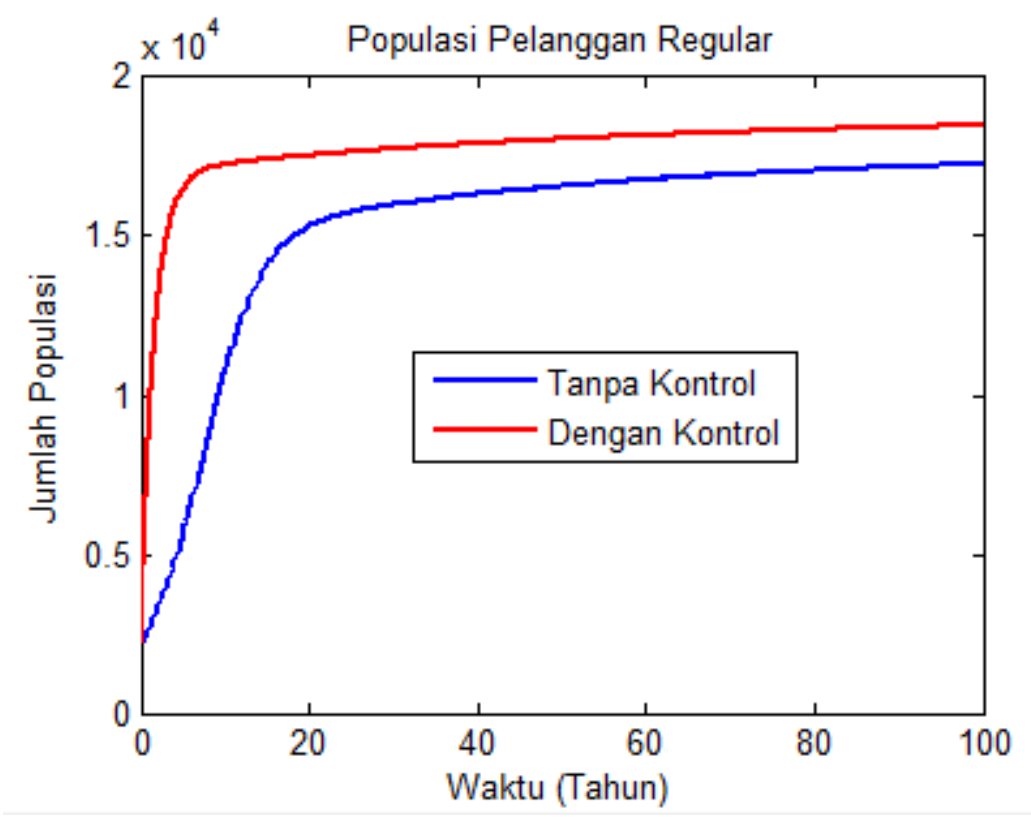

Gambar 5 Simulasi Perbandingan Jumlah Pelanggan Regular (C)

Berdasarkan Gambar 5, jumlah populasi tanpa diberi kontrol naik secara signifikan hingga tahun ke-20 kemudian naik secara bertahap hingga akhir pengamatan. Namun setelah diberi upaya pengiklanan word of mouth, pada awal pengamatan jumlah populasi pelanggan regular naik secara signifikan melebihi jumlah populasi pelanggan regular sebelum diberi upaya kontrol, setelah itu pada tahun ke-7 jumlah populasi naik secara bertahap hingga akhir pengamatan. Berikut ini diberikan tabel perbandingan jumlah pelanggan referral tanpa dan dengan adanya penambahan variabel kontrol yang diamati pada akhir pengamatan.

Tabel 6 Perbandingan Populasi Pelanggan Regular (C) Pada Akhir Pengamatan

\begin{tabular}{|c|c|}
\hline Skenario & Jumlah Populasi $\boldsymbol{C}$ \\
\hline Tanpa Kontrol & 17260 \\
\hline Dengan Kontrol & 18470 \\
\hline
\end{tabular}


Berdasarkan Tabel 6 terlihat bahwa kedua skenario memiliki perbedaan jumlah populasi saat akhir pengamatan. Hal ini mempertegas bahwa pemberian kontrol memberikan efek untuk memaksimalkan jumlah pelanggan regular.

Berdasarkan Gambar 4 - 5 dan Tabel 5 - 6, terlihat bahwa pemberian kontrol optimal berupa pengiklanan produk melalui word of mouth dapat memaksimumkan jumlah populasi pelanggan referral dan pelanggan regular. Hal ini menunjukkan upaya kontrol yang diberikan memberikan efek untuk memaksimumkan jumlah populasi pelanggan referral dan pelanggan regular.

Selanjutnya untuk simulasi profil kontrol disajikan pada Gambar 6 berikut :

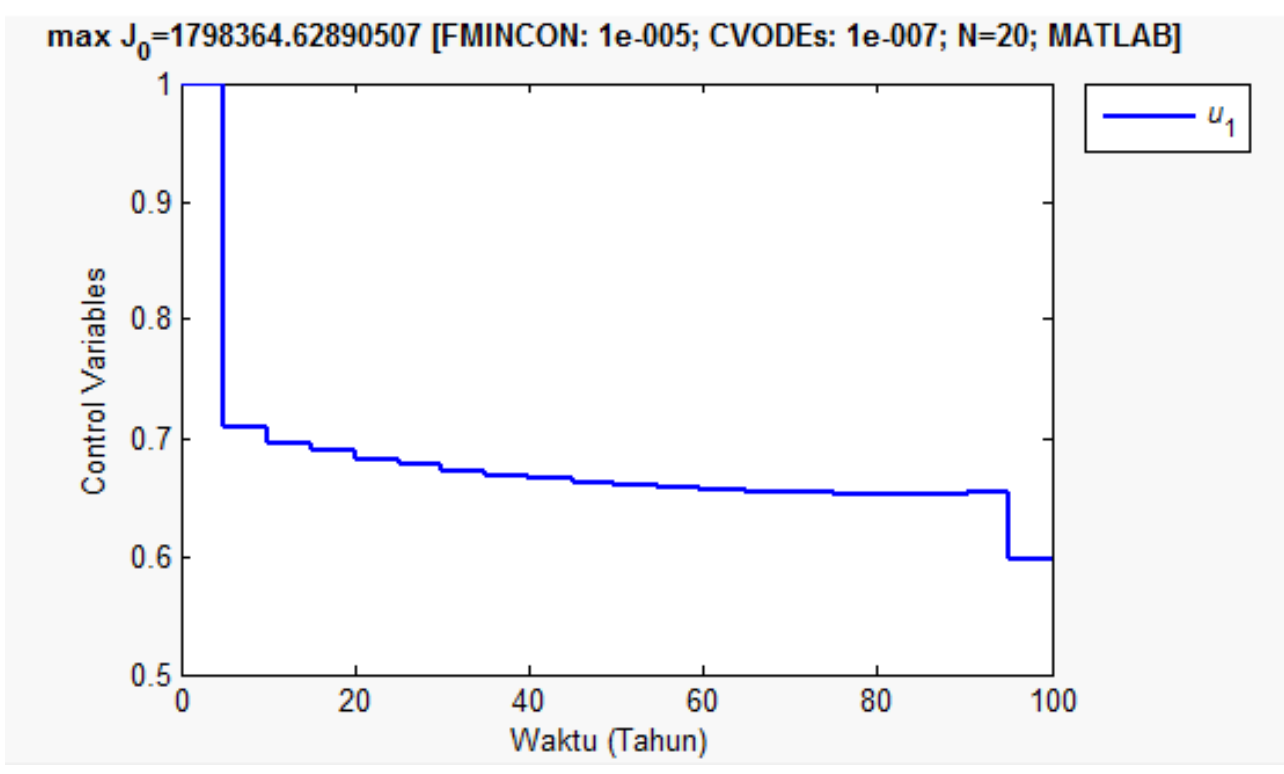

Gambar 6 Profil Kontrol Upaya Pengiklanan Word of Mouth

Gambar 6 menunjukkan grafik pemberian upaya pengiklanan word of mouth hingga tahun ke-100. Pada Gambar 6 terlihat bahwa pemberian upaya pengiklanan word of mouth secara penuh yaitu $100 \%$ sampai tahun ke-5. Setelah itu pada tahun ke-5 sampai tahun ke-90 upaya pengiklanan word of mouth menurun menjadi $65.18 \%$. kemudian pada tahun ke-90 sampai 94 upaya pengiklanan word of mouth ditingkatkan sebesar $65.45 \%$. selanjutnya pada tahun ke-95 sampai 100 usaha pemberian kontrol terus mengalami penurunan hingga 59\%. Dari simulasi yang dilakukan, juga diperoleh biaya upaya pengiklanan word of mouth sebesar 1798364.63. 


\section{Kesimpulan}

Berdasarkan hasil pembahasan yang telah dijelaskan, maka dapat disimpulkan bahwa:

1. Model matematika dinamika pelanggan berdasarkan kebijakan pemasaran memiliki dua titik setimbang, yaitu titik setimbang non endemik $\left(E_{0}\right)$ dan titik setimbang endemik $\left(E_{1}\right)$. Titik setimbang endemik akan stabil asimtotis jika dan hanya jika $R_{0}<1$, sedangkan titik setimbang endemik cenderung stabil asimtotis jika memenuhi $R_{0}>1$, dengan nilai $R_{0}$ sebagai berikut :

$$
\mathrm{R}_{0}=\frac{\Lambda \delta\left(\left(\alpha \mu+\eta_{1}\right)\left(\mu+\beta_{1}+\omega_{1}\right)+\omega_{1}\left[(1-\alpha) \mu+\eta_{2}\right]\right)}{\mu\left(\mu+\eta_{2}+\eta_{1}\right)\left(\left(\mu+\beta_{2}\right)\left(\mu+\beta_{1}+\omega_{1}\right)+\omega_{2}\left(\mu+\beta_{1}\right)\right)}
$$

2. Bentuk kontrol optimal pada model matematika dinamika pelanggan berdasarkan kebijakan pemasaran yang diberi kontrol berupa upaya pengiklanan word of mouth adalah

$$
u^{*}=\min \left(1, \max \left(0, \frac{\psi_{3} \gamma R P_{R}-\psi_{1} \gamma R P_{R}}{\theta}\right)\right) .
$$

3. Berdasarkan hasil simulasi numerik pada model matematika dinamika pelanggan berdasarkan kebijakan pemasaran menunjukkan bahwa, jumlah populasi pelanggan referral dan regular yang diberikan kontrol berupa upaya pengiklanan word of mouth pada akhir pengamatan berturut - turut adalah 312 dan 18470 dengan biaya upaya kontrol yang dikeluarkan sebesar 1798364.63. Sedangkan jumlah populasi pelanggan referral dan regular yang tidak diberikan kontrol berupa upaya pengiklanan word of mouth pada akhir pengamatan berturut - turut adalah 241 dan 17260. Berdasarkan hasil tersebut menunjukkan bahwa, upaya pengiklanan word of mouth memberikan efek untuk meningkatkan jumlah pelanggan referral dan regular sesuai dengan tujuan pemberian kontrol optimal.

\section{Daftar Pustaka}

[1] Rosa, S., Rebelo, P., Silva, C.M., Alves, H., dan Carvalho, P.G., 2018, Optimal Control of the Customer Dynamics Based on Marketing Policy, Applied Mathematics and Computation, 330 : 42-55.

[2] Swastha, B.D., 1999, Loyalitas Pelanggan: Sebuah Kajian Konseptual Sebagai Panduan Bagi Peneliti, Jurnal Ekonomi dan Bisnis Indonesia, 14, No. 3

[3] Silva, C.M., Silvèrio, R., Helena, A., dan Pedro, G.C., 2016, A Mathematical Model for the Customer Dynamics Based on Marketing Policy, Applied Mathematics and Computation, $273: 42-53$.

[4] Latief, R., 2018, Word of Mouth Communication Penjualan Produk, Media Sahabat Cendekia, Surabaya

[5] Li, P., Xiofan, Y., Lu-Xing, Y., Qingyu, X., Yingbo,W., dan Yuan, Y.T., 2018, The Modeling and Analysis of the Word of Mouth Marketing, Phisica A, 493 : 1-16. 
[6] Driessche, P. dan Watmough, J., 2002, Reproduction numbers and sub-threshold endemic equilibria for compartmental models of disease transmission, Mathematical Biosciences, 180:29-48.

[7] Chitnis, N., Hyman, J.M., dan Cushing, 2008, Determine important parameters in the spread of malaria through the sensitivity analysis of mathematics model, Bulletin of Mathematical Biology, 70:1272-1296. 